\title{
IMPLEMENTASI MODEL PEMBELAJARAN KOOPERATIF TIPE NUMBERED HEADS TOGETHER (NHT) UNTUK MENINGKATKAN AKTIVITAS BELAJAR AKUNTANSI
}

\section{THE IMPLEMENTATION OF NUMBERED HEADS TOGETHER (NHT) COOPERATIVE LEARNING MODEL}

\author{
Oleh: Vira Juwita Raharja \\ Prodi Pendidikan Akuntansi Universitas negeri Yogyakarta \\ vjraharja@yahoo.com \\ Rr. Indah Mustikawati \\ Staf Pengajar Jurusan P. Akuntansi Universitas Negeri Yogyakarta
}

\begin{abstract}
Abstrak
Penelitian ini merupakan Penelitian Tindakan Kelas yang bertujuan untuk meningkatkan Aktivitas Belajar Akuntansi siswa melalui Implementasi Model Pembelajaran Kooperatif tipe Numbered Heads Together (NHT) Siswa Kelas X Akuntansi 1 SMK Muhammadiyah Wonosari Tahun Ajaran 2014/2015. Subjek dalam penelitian ini adalah siswa kelas X Akuntansi 1 yang berjumlah 32 siswa. Pengumpulan data dalam penelitian ini dengan observasi, wawancara, dan dokumentasi. Teknik analisis data menggunakan analisis data kualitatif dengan membandingkan persentase skor Aktivitas Belajar Akuntansi siswa pada siklus I dan siklus II. Analisis data kualitatif dianalisis dengan teknik analisis interaktif yaitu Reduksi Data, Penyajian Data, Penarikan Kesimpulan. Berdasarkan hasil penelitian disimpulkan bahwa Implementasi Model Pembelajaran Kooperatif tipe Numbered Heads Together (NHT) dapat meningkatkan Aktivitas Belajar Akuntansi siswa. Hal ini ditunjukkan dengan peningkatan persentase skor rata-rata Aktivitas Belajar Akuntansi siswa sebesar 36,04\%. Hasil observasi siklus I diperoleh rata-rata skor Aktivitas Belajar Akuntansi siswa sebesar 50,93\%. Pada siklus II diperoleh skor sebesar 86,97\%.
\end{abstract}

Kata kunci: Pembelajaran Kooperatif tipe Numbered Heads Together (NHT), Aktivitas Belajar Akuntansi siswa, SMK Muhammadiyah Wonosari

\begin{abstract}
This research is a Classroom Action Research. This research aimed to improve students accounting learning activity through the implementation of Numbered Heads Together (NHT) cooperative learning model in accounting learning of Accounting class 1 grade $X$ SMK Muhammadiyah Wonosari students in the academic year of 2014/2015. The research participants were Accounting class 1 grade $X$ that consisted of 32 students. Observations, interviews, and documentations were done in order to collect the research data. The data analysis technique used in this research was to analyze the data using qualitative data analysis by comparing the students accounting learning activity score percentages from the cycle I and the cycle II. The qualitative data analysis was then analyzed using an interactive analysis technique namely Data Reduction, Data Presentation, and Conclusion Drawing. Based on the research results, the conclusion was that the implementation of Numbered Heads Together (NHT) Cooperative Learning model can improve the students accounting learning activity. This was showed by the improvement of mean score percentage of students accounting learning activity of 36,04\%. From the observation in the cycle I, the mean score of students accounting learning activity was 50,93\%. In the cycle II the mean score got was $86,97 \%$.
\end{abstract}

Keywords: Numbered Heads Together (NHT) Cooperative Learning, students accounting learning activity, SMK Muhammadiyah Wonosari 


\section{A. PENDAHULUAN}

Pendidikan merupakan hal yang sangat penting bagi suatu bangsa. Kualitas suatu bangsa sangat dipengaruhi oleh faktor pendidikan. Pendidikan dalam hal ini dipandang sebagai suatu upaya dalam mempersiapkan sumber daya manusia yang memiliki keahlian dan keterampilan sesuai tuntutan pembangunan nasional.

Berbagai upaya untuk meningkatkan kualitas pendidikan telah dilakukan oleh pemerintah Indonesia untuk memperbaiki dan meningkatkan kualitas pendidikan nasional. Upaya tersebut diantaranya dengan dikeluarkannya UU No. 20 tahun 2003 tentang Sistem Pendidikan Nasional, UU No. 14 tahun 2005 tentang Guru dan Dosen, Permendiknas No. 16 tahun 2007 tentang Standar Kualifikasi Akademik dan Kompetensi Guru, dan Program Wajib Belajar 9 tahun mengikuti pendidikan 6 tahun di sekolah dasar dan 3 tahun di sekolah lanjutan pertama.

Upaya peningkatan kualitas pendidikan tidak lepas dari keberhasilan dalam proses pembelajaran. Dalam keberhasilan proses pembelajaran terdapat faktor yang mempengaruhi, diantaranya faktor guru, faktor siswa, alat dan media yang tersedia, serta faktor lingkungan (Wina Sanjaya. 2013: 52). Faktor guru adalah komponen yang sangat menentukan dalam proses pembelajaran. Keberhasilan pembelajaran dipengaruhi oleh kemampuan guru dalam menggunakan metode, teknik, dan taktik pembelajaran.

Aktivitas siswa merupakan prinsip atau asas yang sangat penting di dalam interaksi belajar-mengajar. Menurut Edi Suardi (Sardiman, 2011: 17), "siswa merupakan sentral maka aktivitas siswa merupakan syarat mutlak bagi berlangsungnya interaksi belajarmengajar". Dengan demikian, guru dalam pelaksanaan pembelajaran diharapkan menempatkan faktor keaktifan siswa sebagai subjek belajar bukan sebagai objek belajar. Namun, masih dijumpai kondisi dimana guru berperan aktif dalam pembelajaran seperti metode pembelajaran yang digunakan dalam pembelajaran masih terbatas konvensional yaitu berupa metode ceramah. Metode ceramah dapat dikatakan sebagai satu-satunya metode yang paling ekonomis untuk menyampaikan informasi. Disamping itu, metode ini dipandang paling efektif untuk mengatasi kelangkaan literatur atau rujukan yang sesuai dengan jangkauan daya beli dan daya paham siswa (Muhibbin Syah, 2013: 200).

Mata pelajaran akuntansi adalah mata pelajaran yang membutuhkan kesabaran, kecermatan, serta ketelitian. Selama ini guru di dalam menyampaikan materi pelajaran akuntansi menggunakan metode ceramah sehingga dirasa membosankan bagi siswa. Oleh karena itu, dalam pembelajaran perlu adanya penggunaan model pembelajaran yang mengutamakan pembelajaran yang menyenangkan, salah satu alternatifnya adalah model pembelajaran kooperatif. Dengan melaksanakan model pembelajaran kooperatif siswa memungkinkan dapat meraih keberhasilan dalam belajar, di samping itu juga bisa melatih siswa untuk memiliki keterampilan, baik keterampilan berpikir (thinking skill) maupun keterampilan sosial (social skill), seperti keterampilan untuk mengemukakan pendapat, menerima saran dan masukan dari orang lain, bekerjasama, rasa setia kawan, dan mengurangi timbulnya perilaku yang menyimpang dalam kehidupan kelas (Stahl dalam Isjoni, 2013: 35).

Salah satu model pembelajaran adalah tipe Numbered Heads Together (NHT). NHT adalah model pembelajaran kelompok yang melibatkan semua siswa memecahkan masalah secara bersamasama, sehingga dapat membangun aktivitas belajar siswa yang pada akhirnya dapat meningkatkan prestasi belajarnya. Menurut Isjoni (2013: 68), "kepala bernomor (Numbered Heads) merupakan teknik yang memberi kesempatan kepada siswa untuk saling memberi kesempatan 
kepada siswa untuk saling membagikan ide-ide dan pertimbangan jawaban yang paling tepat".

Berdasarkan observasi awal pada tanggal 11 Agustus 2014 yang dilakukan di kelas $\mathrm{X}$ Akuntansi 1 SMK Muhammadiyah Wonosari terdapat permasalahan yang terjadi antara lain siswa kurang fokus dalam pembelajaran, misalnya mengobrol dengan teman lain, melamun dan mengantuk. Selain itu siswa harus diingatkan untuk mendengarkan dan memperhatikan penjelasan guru sehingga terkadang guru memaksa siswa untuk memperhatikan pelajaran. Berdasarkan hasil observasi, dari 32 siswa 8 siswa aktif menjawab pertanyaan guru dan siswa yang lain mengobrol, mengantuk, dan diam mendengarkan penjelasan guru. Dengan demikian dapat disimpulkan, $25 \%$ siswa yang berpartisipasi aktif. Ketika mengerjakan tugas dari guru siswa juga kurang mandiri untuk menyelesaikan pekerjaannya terlihat ada siswa yang meminjam pekerjaan temannya sehingga siswa hanya sekedar menyontek jawaban tanpa ada usaha untuk menyelesaikan sendiri.

Berdasarkan uraian singkat di atas peneliti tertarik melakukan penelitian dengan judul "Implementasi Model Pembelajaran Kooperatif Tipe Numbered Heads Together (NHT) untuk meningkatkan Aktivitas Belajar Akuntansi Siswa Kelas X Akuntansi 1 SMK Muhammadiyah Wonosari Tahun Ajaran 2014/2015".

\section{B. METODE PENELITIAN \\ 1. Jenis Penelitian}

Jenis penelitian ini adalah Penelitian Tindakan Kelas dalam bentuk kolaborasi. Dalam penelitian kolaborasi, pihak yang melakukan tindakan adalah guru, sedangkan yang melakukan pengamatan terhadap berlangsungnya proses tindakan adalah peneliti.

\section{Tempat dan Waktu Penelitian}

Penelitian ini dilaksanakan di kelas $\mathrm{X}$ Akuntansi 1 Program Keahlian Akuntansi SMK Muhammadiyah Wonosari yang beralamat di Jalan Alunalun No. 11 Wonosari, Kepek, Gunungkidul 55813. Adapun penelitian ini dilaksanakan pada semester ganjil bulan November sampai Desember tahun ajaran $2014 / 2015$.

\section{Target/Subjek Penelitian}

Subjek penelitian ini adalah seluruh siswa kelas X Akuntansi 1 SMK Muhammadiyah Wonosari tahun ajaran 2014/2015 yang berjumlah 32 orang.

\section{Prosedur}

Penelitian Tindakan Kelas adalah penelitian tindakan yang dilakukan di kelas dengan tujuan memperbaiki/meningkatkan mutu pendidikan. Secara garis besar terdapat empat tahapan yang lazim dilalui, yaitu (1) perencanaan, (2) pelaksanaan, (3) pengamatan, (4) refleksi (Suharsimi Arikunto, 2008: 16).

\section{Data, Instrumen, dan Teknik Pengumpulan}

a) Data

1) Observasi

Jenis observasi yang dilakukan adalah observasi partisipasif. Peneliti mengamati langsung proses pembelajaran di kelas untuk mendapatkan data tentang Aktivitas Belajar Akuntansi. Hasil pengamatan dicatat pada lembar observasi yang telah dipersiapkan.

2) Wawancara

Subjek yang diwawancarai dalam penelitian ini adalah guru mata pelajaran akuntansi dan siswa yang dipilih secara acak. Wawancara digunakan untuk mengetahui kegiatan, informasi maupun perasaan pada saat pengimplementasian model pembelajaran kooperatif tipe NHT. Wawancara dilaksanakan semi structured dimana pelaksanaannya lebih bebas. 
3) Dokumentasi

Dalam penelitian ini, dokumen yang akan digunakan berupa data tentang nama siswa sebagai dasar dalam penentuan anggota kelompok, silabus untuk acuan pembuatan Rencana Pelaksanaan Pembelajaran (RPP).

\section{b) Teknik Analisis Data}

Data hasil observasi dianalisis dengan menggunakan analisis data kualitatif. Data hasil wawancara dianalisis dengan teknik analisis interaktif yang terdiri atas 3 komponen kegiatan yaitu Reduksi Data, Penyajian Data, Penarikan Kesimpulan.

$$
\mathrm{P} \%=\frac{\text { Jumlah Skor Indikator Aktivitas Belajar }}{\text { Jumlah Skor Ideal }} \mathrm{X} 100 \%
$$

Keterangan: $\mathrm{P} \%=$ Persentase siswa yang aktif (Sugiyono, 2012: 137)

\section{HASIL PENELITIAN DAN PEMBAHASAN}

1. Hasil Penelitian Siklus I

Dalam tahap pengamatan, peneliti dan observer mengamati jalannya Pembelajaran Akuntansi di Kelas X Akuntansi 1 dan mengamati Aktivitas Belajar siswa menggunakan pedoman observasi dan lembar observasi. Berikut ini hasil pengamatan Aktivitas Belajar siswa yang berjumlah 27 siswa pada siklus:

Tabel 1. Hasil Observasi Aktivitas Belajar Siswa Siklus I

\begin{tabular}{|l|l|c|}
\hline No & \multicolumn{1}{|c|}{ Indikator } & $\%$ \\
\hline 1 & $\begin{array}{l}\text { Siswa terlibat baik secara } \\
\text { fisik, mental, dan } \\
\text { emosional dalam setiap } \\
\text { proses pembelajaran }\end{array}$ & \\
\hline 2 & $\begin{array}{l}\text { Siswa terlibat dalam } \\
\text { menjawab dan mengajukan } \\
\text { pertanyaan }\end{array}$ & $\begin{array}{l}\text { Siswa berusaha } \\
\text { memecahkan masalah yang } \\
\text { diajukan atau yang muncul } \\
\text { selama proses pembelajaran } \\
\text { berlangsung }\end{array}$ \\
\hline 3 & $\begin{array}{l}\text { Siswa berinteraksi dengan } \\
\text { siswa lain maupun dengan } \\
\text { guru terkait proses }\end{array}$ & \\
\hline
\end{tabular}

\begin{tabular}{|c|c|c|}
\hline & $\begin{array}{l}\text { pembelajaran terkait proses } \\
\text { pembelajaran }\end{array}$ & \\
\hline 5 & $\begin{array}{l}\text { Siswa terlibat dalam } \\
\text { evaluasi hasil diskusi atas } \\
\text { soal yang di berikan }\end{array}$ & $33,33 \%$ \\
\hline 6 & $\begin{array}{l}\text { Siswa mampu menyusun } \\
\text { laporan hasil diskusi baik } \\
\text { secara tertulis maupun lisan } \\
\text { berkenaan dengan hasil } \\
\text { belajar yang diperolehnya }\end{array}$ & $46,30 \%$ \\
\hline \multicolumn{2}{|c|}{$\begin{array}{c}\text { Rata-rata Aktivitas Belajar } \\
\text { Akuntansi Siswa Pada Siklus I }\end{array}$} & $50,93 \%$ \\
\hline
\end{tabular}

Tabel tersebut menjelaskan bahwa ratarata Aktivitas Belajar siswa pada Siklus I sebesar 50,93\%. Hal tersebut menunjukkan bahwa rata-rata Aktivitas Belajar siswa belum mencapai kriteria minimal, yaitu sebesar $75 \%$. Berdasarkan tabel hasil observasi Aktivitas Belajar siswa siklus I, maka Aktivitas Belajar siswa dapat dilihat melalui grafik sebagai berikut:

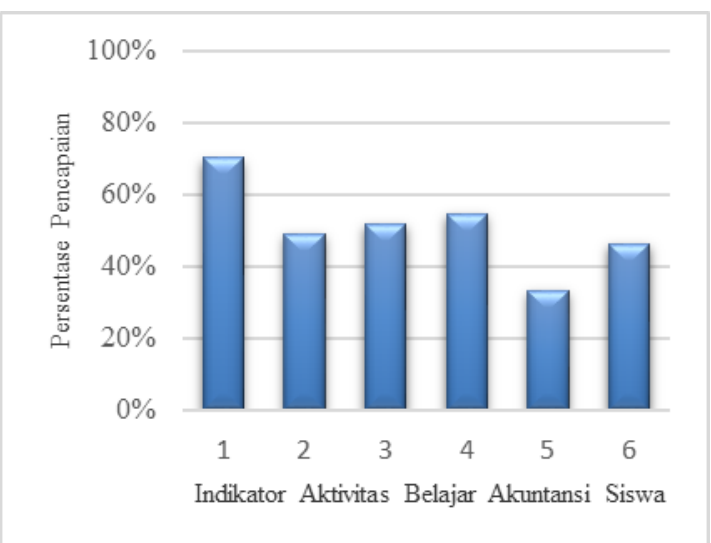

Gambar 1. Aktivitas Belajar Akuntansi Siklus I

\section{Hasil Penelitian Siklus II}

Dari pengamatan yang telah dilakukan dalam Siklus II dan dilakukan perbaikan dari hasil kekurangan siklus I diperoleh data sebagai berikut:

Tabel 2. Hasil Observasi Aktivitas Belajar Siswa Siklus II

\begin{tabular}{|l|l|c|}
\hline No & \multicolumn{1}{|c|}{ Indikator } & $\%$ \\
\hline 1 & $\begin{array}{l}\text { Siswa terlibat baik secara } \\
\text { fisik, mental, dan } \\
\text { emosional dalam setiap } \\
\text { proses pembelajaran }\end{array}$ & \\
\hline
\end{tabular}




\begin{tabular}{|c|c|c|}
\hline 2 & $\begin{array}{lr}\text { Siswa terlibat dalam } \\
\text { menjawab dan } \\
\text { mengajukan pertanyaan }\end{array}$ & $80,17 \%$ \\
\hline 3 & $\begin{array}{l}\text { Siswa berusaha } \\
\text { memecahkan masalah } \\
\text { yang diajukan atau yang } \\
\text { muncul selama proses } \\
\text { pembelajaran berlangsung }\end{array}$ & $85,63 \%$ \\
\hline 4 & $\begin{array}{l}\text { Siswa berinteraksi dengan } \\
\text { siswa lain maupun dengan } \\
\text { guru terkait proses } \\
\text { pembelajaran terkait } \\
\text { proses pembelajaran }\end{array}$ & $87,93 \%$ \\
\hline 5 & $\begin{array}{l}\text { Siswa terlibat dalam } \\
\text { evaluasi hasil diskusi atas } \\
\text { soal yang di berikan }\end{array}$ & $72,41 \%$ \\
\hline 6 & $\begin{array}{l}\text { Siswa mampu menyusun } \\
\text { laporan hasil diskusi baik } \\
\text { secara tertulis maupun } \\
\text { lisan berkenaan dengan } \\
\text { hasil belajar } \\
\text { diperolehnya }\end{array}$ & $100 \%$ \\
\hline \multicolumn{2}{|c|}{$\begin{array}{l}\text { Rata-rata Aktivitas Belajar } \\
\text { Akuntansi Siswa Pada Siklus I }\end{array}$} & $86,97 \%$ \\
\hline
\end{tabular}

Tabel tersebut menunjukkan bahwa ratarata Aktivitas Belajar Siswa pada Siklus II sebesar $86,97 \%$. Hal tersebut menunjukkan rata-rata Aktivitas Belajar siswa sudah mencapai kriteria minimal, yaitu sebesar $75 \%$. Berdasarkan Tabel Hasil Observasi Aktivitas Belajar Siswa Siklus II, maka Aktivitas Belajar Siswa dapat dilihat melalui grafik sebagai berikut:

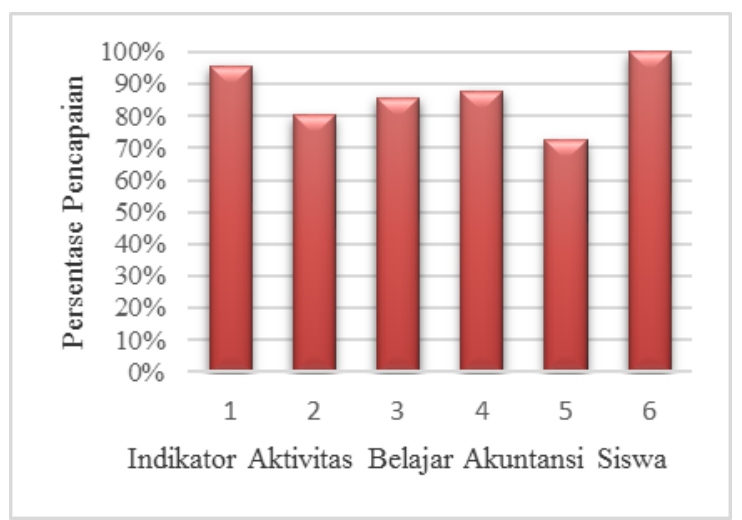

Gambar 2. Diagram Batang Aktivitas Belajar Akuntansi Siklus II

\section{Pembahasan}

Dari penelitian yang dilakukan dengan Model Pembelajaran Kooperatif tipe Numbered Heads Together (NHT) dalam Pembelajaran Akuntansi pada siswa Kelas X Akuntansi SMK Muhammadiyah Wonosari Tahun Ajaran 2014/2015 baik pada siklus I maupun siklus II, maka siswa menunjukkan aktivitas-aktivitas yang mendukung proses pembelajaran. Hal ini ditunjukkan dari skor Aktivitas Belajar Akuntansi siswa pada setiap siklus dilihat dari masing-masing indikator. Berikut ini disajikan data Aktivitas Belajar Akuntansi siswa pada tindakan siklus I dan siklus II: Tabel 3. Hasil Observasi Aktivitas Belajar Akuntansi Siswa Siklus I dan Siklus II

\begin{tabular}{|c|c|c|c|c|}
\hline \multirow[t]{2}{*}{$\begin{array}{l}\mathrm{N} \\
\mathrm{O}\end{array}$} & \multirow[t]{2}{*}{ Indikator } & \multicolumn{2}{|c|}{$\begin{array}{c}\% \text { Aktivitas } \\
\text { Belajar } \\
\text { Akuntansi Siswa }\end{array}$} & $\begin{array}{c}\text { Pening } \\
\text { katan }\end{array}$ \\
\hline & & $\begin{array}{l}\text { Siklus } \\
\text { I }\end{array}$ & $\begin{array}{c}\text { Siklus } \\
\text { II }\end{array}$ & I-II \\
\hline 1 & $\begin{array}{l}\text { Siswa terlibat } \\
\text { baik secara fisik, } \\
\text { mental, dan } \\
\text { emosional } \\
\text { dalam setiap } \\
\text { proses } \\
\text { pembelajaran }\end{array}$ & $70,37 \%$ & $95,69 \%$ & $25,32 \%$ \\
\hline 2 & $\begin{array}{l}\text { Siswa terlibat } \\
\text { dalam } \\
\text { menjawab dan } \\
\text { mengajukan } \\
\text { pertanyaan }\end{array}$ & $49,07 \%$ & $80,17 \%$ & $31,10 \%$ \\
\hline 3 & $\begin{array}{l}\text { Siswa berusaha } \\
\text { memecahkan } \\
\text { masalah yang } \\
\text { diajukan atau } \\
\text { yang muncul } \\
\text { selama proses } \\
\text { pembelajaran } \\
\text { berlangsung }\end{array}$ & $51,85 \%$ & $85,63 \%$ & $33,78 \%$ \\
\hline 4 & $\begin{array}{l}\text { Siswa } \\
\text { berinteraksi } \\
\text { dengan siswa } \\
\text { lain maupun } \\
\text { dengan guru } \\
\text { terkait proses } \\
\text { pembelajaran } \\
\text { terkait proses } \\
\text { pembelajaran }\end{array}$ & $54,63 \%$ & $87,93 \%$ & $33,30 \%$ \\
\hline
\end{tabular}




\begin{tabular}{|c|c|c|c|c|}
\hline 5 & $\begin{array}{lr}\text { Siswa } & \text { terlibat } \\
\text { dalam evaluasi } \\
\text { hasil diskusi } \\
\text { atas soal yang di } \\
\text { berikan }\end{array}$ & $33,33 \%$ & $72,41 \%$ & $39,08 \%$ \\
\hline 6 & \begin{tabular}{lr} 
Siswa mampu \\
menyusun \\
laporan hasil \\
diskusi baik \\
secara tertulis \\
maupun lisan \\
berkenaan \\
dengan hasil \\
belajar yang \\
\multicolumn{2}{l}{ diperolehnya } \\
\end{tabular} & $46,30 \%$ & $100 \%$ & $53,70 \%$ \\
\hline \multicolumn{2}{|c|}{$\begin{array}{c}\text { Rata-rata Aktivitas } \\
\text { Belajar Akuntansi } \\
\text { Siswa }\end{array}$} & $\begin{array}{c}\mathbf{5 0 , 9 3} \\
\%\end{array}$ & $\begin{array}{c}86,97 \\
\%\end{array}$ & $36,04 \%$ \\
\hline
\end{tabular}

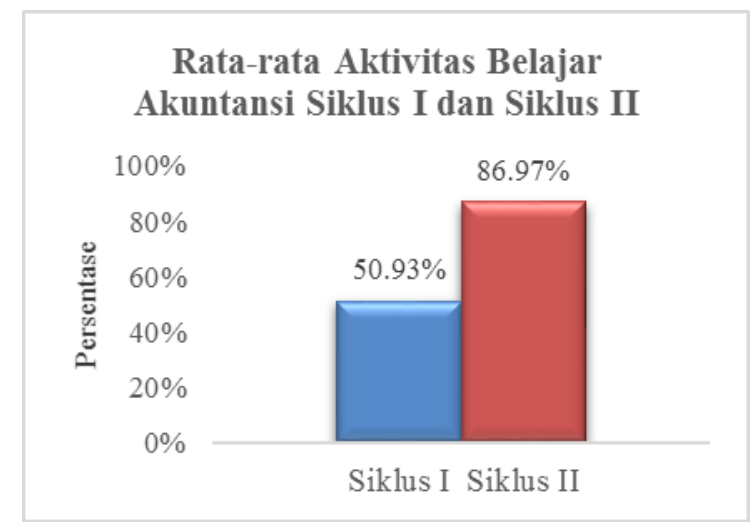

Gambar 3. Grafik Rata-rata Persentase Aktivitas Belajar Akuntansi Siswa pada Siklus I dan II

Tabel dan gambar di atas menunjukkan bahwa pada masing-masing siklus terjadi peningkatan Aktivitas Belajar Akuntansi siswa. Skor rata-rata Aktivitas Belajar Akuntansi siswa pada siklus I sebesar 50,93\%. Skor ini didapatkan dari skor Aktivitas Belajar Akuntansi siswa dari setiap aspek yang terdapat pada indikator yang telah ditentukan. Skor ratarata pada siklus I tersebut belum mecapai kriteria minimal yang ditentukan sebesar $75 \%$, sehingga tindakan dilanjutkan lagi sampai siklus II agar terjadi peningkatan pada Aktivitas Belajar Akuntansi siswa. Setelah dilakukan tindakan siklus II, skor rata-rata Aktivitas Belajar Akuntansi siswa meningkat menjadi sebesar $86,97 \%$. Skor tersebut sudah mencapai kriteria minimal yang ditentukan. Hasil di atas juga memperlihatkan bahwa terjadi peningkatan rata-rata skor Aktivitas Belajar Akuntansi siswa dari siklus I ke siklus II sebesar $36,04 \%$.

\section{SIMPULAN DAN SARAN \\ 1. Simpulan}

Berdasarkan hasil penelitian dan pembahasan pada bab IV dapat disimpulkan bahwa Implementasi Model Pembelajaran Kooperatif tipe Numbered Heads Together (NHT) dapat meningkatkan Aktivitas Belajar Akuntansi Siswa Kelas X Akuntansi 1 SMK Muhammadiyah Wonosari tahun ajaran 2014/2015.

2. Saran

a) Guru dapat mencoba untuk mengimplementasikan Model Pembelajaran Kooperatif tipe Numbered Heads Together (NHT) dan guru sebaiknya meningkatkan pemberian motivasi kepada siswa untuk aktif menjawab pertanyaan dan bertanya kepada guru.

b) Penelitian selanjutnya diharapkan dapat melakukan penelitian yang hasilnya dapat menunjukkan kondisi dari masing-masing kelompok dan mampu memperbaiki aspek-aspek yang diamati dalam aktivitas belajar sehingga dapat menunjukkan peningkatan aktivitas belajar siswa secara keseluruhan.

\section{E. DAFTAR PUSTAKA}

Isjoni. (2013). Pembelajaran Kooperatif Untuk Meningkatkan Kecerdasan Komunikasi Antar Peserta Didik. Yogyakarta: Pustaka Pelajar.

Muhibbin Syah. (2013). Psikologi Pendidikan dengan Pendidikan 
Baru Edisi Revisi. Bandung: PT Remaja Rosda Karya.

Permendiknas No. 16 tahun 2007 tentang Standar Kualifikasi Akademik dan Kompetensi Guru.

Sardiman AM. (2011). Interaksi dan Motivasi Belajar Mengajar. Jakarta: PT. Rajagrafindo Persada.

Sugiyono. (2012). Metode Penelitian Pendidikan. Bandung: CV Alfabeta.

(2012). Metode Penelitian
Pendidikan
Kuantitatif, Kualitatif, dan R\&D. $R$.
Bandung: Alfabeta.

Suharsimi Arikunto dkk. (2008). Penelitian Tindakan Kelas. Jakarta: Bumi Aksara.

Undang-undang Republik Indonesia Nomor 14 tahun 2005 tentang Guru dan Dosen.

Undang-undang Republik Indonesia Nomor 20 tahun 2003 tentang Sistem Pendidikan Nasional.

Wina Sanjaya. (2013). Strategi Pembelajaran Berorientasi Standar Proses Pendidikan. Jakarta: Kencana. 